\title{
Study of Pulmonary Function Test in Type 2 Diabetics and COPD with Diabetes
}

Giri SG, Kapse VR*, Barade SB and Mhaisekar DG

Department of Pulmonary Medicine, Dr Shankar Rao Chavan Government Medical College, Nanded, Maharashtra, India

\begin{abstract}
Introduction: The association of reduced lung functions and diabetes mellitus has been described for many years suggesting that the lung could be a target organ in diabetes mellitus. Chronic obstructive Pulmonary Disease is considered as a disease that goes beyond lung involvement giving it an expression of multisystem inflammatory disease. Diagnosis of Chronic Obstructive Pulmonary Disease in diabetics may have difficulties due to superimposition of restrictive abnormality associated with diabetes mellitus.
\end{abstract}

Aim: To study pulmonary function test in type 2 Diabetics and in COPD with type 2 Diabetes.

Materials and Methods: The study was conducted in Department of Pulmonary Medicine at Dr. Shankar rao Chavan Govt Medical College, Nanded. After inclusion criteria were met, patients were divided into 3 groups (40 type 2 diabetes with COPD (Group A), 40 type 2 diabetics (Group B), and 40 healthy controls (Group C) who are nonsmoker and having no history of any acute or chronic respiratory illness.) which underwent clinical evaluation and spirometry was performed.

Results: The spirometric parameters shows that among 40 patients of DM with COPD 22 (55\%) had restrictive, $12(30 \%)$ had obstructive,06 (15\%) had mixed and 0 patients were normal and among 40 patients of DM $26(65 \%)$ had restrictive, $06(15 \%)$ had obstructive,06 (15\%) had mixed and $02(05 \%)$ patients were normal spirometric findings. We also compared duration of diabetes with spirometric findings (FEV1, FVC, FEV1/FVC) in both the groups so we found no correlation between them $(p>0.05)$.

Conclusion: The finding in our study proved that patients with type 2 DM with COPD showed additional restriction pattern on spirometry with compared usual obstructive pattern, also further we found that in patients with Type 2 DM we also found restrictive pattern. So we can conclude that DM being a systemic disease, also affects lung causing restrictive type of ventilatory changes. The restrictive changes probably because of glycosylation of connective tissues reduced pulmonary elastic recoil and inflammatory changes in lungs.

Keywords: COPD; Type 2 diabetics; Pulmonary function test; Spirometry

\section{Introduction}

Diabetes mellitus type 2 is a metabolic disorder that is characterized by high blood glucose in the context of insulin resistance and relative insulin deficiency [1]. This is typically a multi-organ chronic disease and is associated with a ten-year-shorter life expectancy due to its complications [2]. World Health Organization estimates that more than 180 million people worldwide have diabetes, and by 2030 it is expected that this number will have doubled [3]. There is an alarming increase in the incidence and prevalence of diabetes mellitus (DM) in Indians [4]. Diabetes has micro-vascular and macro-vascular disorder with debilitating effects on many organs. The alveolar capillary network in the lung is a large micro-vascular unit and may be affected by microangiopathy [5]. However, because of its large reserve, substantial loss of the micro-vascular bed can be tolerated without developing dyspnoea. As a result, pulmonary diabetic micro-angiopathy usually remains under-recognized clinically.

Among these, Diabetes mellitus (DM) is one frequent comorbidity encountered in patients with COPD which can have a significant impact on the course of the disease. COPD and DM, both being proinflammatory conditions, they share relevant features in their genesis and course. COPD patients more prone to develop type $2 \mathrm{DM}$ due to multiple risk factors like obesity, sedentary lifestyle, smoking, increased inflammation, oxidative stress and corticosteroid therapy. DM affects $2-37 \%$ of people with COPD, depending on the patient subgroup studied. In population studies, COPD is consistently associated with a 1.4-2.0 fold increased risk of DM [6]. Decrements in lung functions in patients with type $2 \mathrm{DM}$ are believed to be the consequence of biochemical alterations in the connective tissue constituents of the lung particularly elastin and collagen as well as micro angiopathy due to the non-enzymatic glycosylation of proteins and the extracellular matrix or lung parenchyma, thickening of basal lamina, increased susceptibility to infection and a modified sarcolemma with subsequent skeletal muscle weakness which are induced by chronic hypoglycaemia. Diabetic microangiopathy itself alters the alveolar diffusion capacity of the lungs [7-11].

The assessment of spirometric parameters is important in diagnosis of COPD. The diagnosis of COPD in patient with DM is difficult due to superimposed restrictive pattern on spirometry as obstructive pattern is predominantly found in these patients. In this study, we assessed and compared the spirometric parameters and duration of DM in patient with COPD with DM and DM without history of acute or chronic

${ }^{*}$ Corresponding author: Vijaykumar R Kapse, Department of Pulmonary Medicine, Dr Shankar Rao Chavan Government Medical College, Nanded, Maharashtra, India, Tel: 9881825252; E-mail: pravin1702@gmail.com

Received January 01, 2019; Accepted January 29, 2019; Published February 05, 2019

Citation: Giri SG, Kapse VR, Barade SB, Mhaisekar DG (2019) Study of Pulmonary Function Test in Type 2 Diabetics and COPD with Diabetes. J Pulm Respir Med 9: 485. doi: 10.4172/2161-105X.1000485

Copyright: ( 2019 Giri SG, et al. This is an open-access article distributed under the terms of the Creative Commons Attribution License, which permits unrestricted use, distribution, and reproduction in any medium, provided the original author and source are credited. 
respiratory illness with that of healthy controls.

\section{Materials and Methods}

The study was conducted in Dept. Of Pulmonary Medicine, Dr. Shankarrao Chavan Govt. Medical College and Hospital, Nanded. The study was carried out after approval from the ethical committee and fully informed written consent from the subjects. A detailed case history proforma was filled out during the recruitment of the patients. This is a case control study carried from January 2016 to August 2017. The following three groups of subjects were included: 40 Type $2 \mathrm{DM}$ patients with COPD (Group A), 40 Type 2 DM patients (Group B) and 40 non-diabetics, non-smoker controls (Group C) with no chest complaints. A total 120 consecutive subjects were included in the study depending on the criteria till the sample size of each group was met.

The patients were recruited as per the following criteria:

1) Type 2 Diabetes Mellitus: Symptoms of diabetes plus fasting plasma glucose $\geq 126 \mathrm{mg} / \mathrm{dl}$ two-hour plasma glucose $200 \mathrm{mg} / \mathrm{dl}$ during an oral glucose tolerance test [12]

2) COPD: Post bronchodilator FEV1/FVC $<70 \%$ post bronchodilator change in FEV1 $<12 \%$ and clinical correlation (exposure to cigarettes or bidis and/or environmental or occupational pollutants; and/or presence of cough, sputum production or Dyspnoea) [13]

\section{Inclusion criteria}

1 . Age $>13$ years.

2. Those subjects giving informed consent to participate in the study.

3. Inclusion of cases and controls will be:

Cases: Patients with Type 2 DM of at least 6 months' duration with-

\section{Group A (DM with COPD)}

- All the patients who are diagnosed as COPD according to Global Initiative for Chronic Obstructive Lung Disease (GOLD) Criteria-2017 and suffering with type 2 Diabetes Mellitus (DM) will be enrolled in the study.

- Patients already on treatment for COPD by a chest physician or newly diagnosed COPD patients based on post-bronchodilator FEV1/FVC $<0.7$ on spirometry.

\section{Group B (Only DM)}

- Subjects who never smoked and no past history of acute and chronic respiratory illness.

\section{Group C (Controls) (Healthy subjects)}

- Subjects who are Non-diabetic and who never smoked and no past history of acute and chronic history of respiratory illness.

- Controls were selected from relatives of the cases who give informed Consent to participate in the study.

\section{Exclusion criteria}

1. Patients age less than 13 years.

2. Patients not willing to participate in the study.

\section{Cases}

\section{Group A (DM with COPD)}

- Patients having history of ILD, lung cancer, present or past history of tuberculosis and decompensated cardiac disease.

- Patients with gross abnormalities of vertebral column or thoracic cage, Neuromuscular disease.

- Patients with major psychiatric illness and those who had gone major abdominal and chest surgery.

\section{Group B (DM only)}

- Present or past history of respiratory diseases that might affects lung function such as Asthma, COPD, tuberculosis, bronchiectasis, interstitial lung disease.

- History of occupational exposure to any substances that could affect the lung functions.

- Individuals with unacceptable spirometric technique. An unacceptable spirometry was that in which FEV1/FVC could not be correctly measured due to-Cough, Obstruction of teeth or tongue, air escape, lack of understanding of the procedure.

\section{Group C (Controls) (Healthy subjects)}

- Subjects who do not give informed consent and not ready to participate in study.

Patients were first evaluated on the basis of clinical parameters Age, Gender, Height (in meter), weight (in kg), systolic and diastolic blood pressure (in $\mathrm{mm} \mathrm{Hg}$ ) were noted along with detail history. Detail clinical examination was done for all the patients. Then all necessary investigations and spirometry and PEFR were done, in order to confirm the diagnosis of patient and also fasting and post prandial blood glucose is measured. Patients were categorized into Obstructive and restrictive respiratory PFT patterns.

\section{Statistical analysis}

All the data collected and filled in Microsoft office excel 2016 sheet. Data was tabulated, all the calculation done with software present in Microsoft office excel 2016. In this study Biostatistics calculations done with Statistical Package for the Social Sciences (SPSS)-16. The demographic, biochemical and spiromeric parameters compared by Unpaired ' $\mathrm{t}$ ' test and the association with duration were estimated by one-way ANOVA test.

\section{For spirometry}

After physical examination and investigations, an informed consent was obtained from all the patients. Patients were informed regarding withholding bronchodilator medications and smokers were instructed for abstinence from smoking. Patients were also instructed about the maneuver thoroughly prior to testing and were also positioned in a proper way. In all patients' baseline Spirometry was done with computerized Medgraphics Spirometer. This Spirometer met American thoracic society criteria and was volume calibrated daily.

Measurement accuracy of Spirometer was $+2 \%$. The patient was subjected to Spirometric study in PFT lab. Bronchodilator response was assessed by giving nebulized salbutamol in a dosage of $2.5 \mathrm{mg}(0.5$ $\mathrm{ml}$ ) diluted with $2 \mathrm{ml} .0 .9 \%$ normal saline. Available as $5 \mathrm{mg} / \mathrm{ml} .15$ minutes after nebulization with salbutamol, Spirometry was performed. The best of three consecutive measurements were taken. Patients were categorized into Obstructive, restrictive, mixed and Normal respiratory diseases and also categorised according to their severity (Figure 1).

\section{Results}

The study included 120 patients who categorized in 3 groups. 
Citation: Giri SG, Kapse VR, Barade SB, Mhaisekar DG (2019) Study of Pulmonary Function Test in Type 2 Diabetics and COPD with Diabetes. J Pulm Respir Med 9: 485. doi: 10.4172/2161-105X.1000485

Page 3 of 5

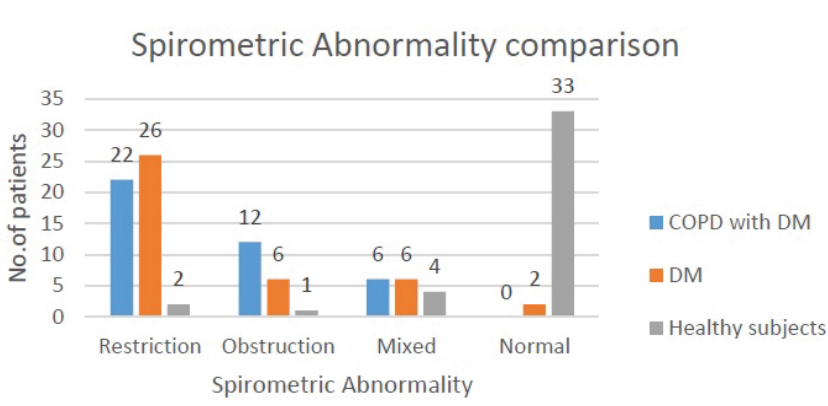

Figure 1: Spirometric abnormality comparison.

1. Group A - (DM with COPD)

2. Group B - (Only DM)

3. Group C - (Healthy subjects/Controls)

Their demographic and biochemical profiles are presented in Table 1 and Table 2. There was no significant difference in Height, Weight, age, sex and BMI distribution of individuals across the three groups. The mean fasting and post prandial blood sugar level was increased in Group A and Group B.

\section{The Pulmonary function tests}

The various parameters of Pulmonary function test have been presented in Tables 3 and 4. After comparing parameters, Table 3 shows that lung functions were reduced in Group A (COPD with DM) as compared to Group C (Healthy subjects), Also Table 4 shows that lung functions were reduced in Group B (DM) as compared to Group $\mathrm{C}$ (Healthy controls). It could be interpreted that the presence of DM worsens the lung functions including FVC,FEV1,FEF 25-75 and PEF and pushes the COPD patients to next severity stage.

\section{Types of spirometric abnormality}

As per Table 5 out of 40 Diabetes with COPD (Group A) patients $22(55 \%)$ have restrictive pattern, $12(30 \%)$ have obstructive pattern, 06 (15\%) have mixed pattern. And in Diabetics (Group B) 26 (65\%) have restrictive pattern, $06(15 \%)$ have obstructive pattern, $06(15 \%)$ have mixed pattern.

In the study association of Pulmonary Function Tests with duration of DM in Group A was shown in the above Table 6, There is no association between FEV1, FVC and FEV1/FVC with duration of diabetes as the $\mathrm{P}$ values for FEV1, FVC and FEV 1/FVC were $0.658,0.328$ and 0.556 respectively which were statistically not significant.

In the study association of Pulmonary Function Tests with duration of DM was shown in the above Table 7. There is no association between FEV1, FVC and FEV1/FVC with duration of diabetes as the P values for FEV1, FVC and FEV1/FVC were $0.921,0.360$ and 0.112 respectively which were statistically not significant.

\section{Discussion}

In this study 40 patients with DM with COPD (Group A) and 40 patients with DM (Group B) satisfying inclusion criteria attending outpatient and indoor patients of a tertiary care government hospital were compared with 40 healthy subjects (Group C) which were matched with Group A and B on basis of age, height, weight and BMI from January 2016 to August 2017 over a period of 18 months.

All the patients included in this study were subjected to detail

\begin{tabular}{|c|c|c|c|}
\hline Variables & $\begin{array}{c}\text { Diabetics with COPD } \\
\text { (Group-A) (Mean } \pm \text { SD) }\end{array}$ & $\begin{array}{c}\text { Healthy subjects (Group-C) } \\
\text { (Mean } \pm \text { SD) }\end{array}$ & $\begin{array}{c}\mathbf{p} \\
\text { value }\end{array}$ \\
\hline Height & $163.55 \pm 2.78$ & $161 \pm 3.02$ & 0.16 \\
\hline Weight & $67.38 \pm 5.51$ & $62.42 \pm 5.59$ & 0.06 \\
\hline BMl & $25.35 \pm 2.08$ & $23.91 \pm 2.52$ & 0.07 \\
\hline Age & $52.82 \pm 8.24$ & $52.25 \pm 9.98$ & 0.78 \\
\hline $\begin{array}{c}\text { FBS (mg/ } \\
\text { dl) }\end{array}$ & $118.95 \pm 11.24$ & $107.05 \pm 31.73$ & 0.002 \\
\hline $\begin{array}{c}\text { PPBS } \\
\text { (mg/dl) }\end{array}$ & $177.40 \pm 32.15$ & $129.45 \pm 8.96$ & $<0.05$ \\
\hline
\end{tabular}

Table 1: Demographic and biochemical profile of DM with COPD with healthy subjects.

\begin{tabular}{|c|c|c|c|}
\hline Variables & $\begin{array}{c}\text { Diabetics with COPD } \\
\text { (Group-B) (Mean } \pm \text { SD) }\end{array}$ & $\begin{array}{c}\text { Healthy subjects (Group-C) } \\
\text { (Mean } \pm \text { SD) }\end{array}$ & $\begin{array}{c}\mathbf{p} \\
\text { value }\end{array}$ \\
\hline Height & $162.0 \pm 3.60$ & $161.95 \pm 3.02$ & 0.947 \\
\hline Weight & $66.73 \pm 5.60$ & $62.42 \pm 5.59$ & 0.42 \\
\hline BMI & $25.45 \pm 2.50$ & $23.91 \pm 2.52$ & 0.087 \\
\hline Age & $53.90 \pm 9.46$ & $52.25 \pm 9.98$ & 0.45 \\
\hline $\begin{array}{c}\text { FBS (mg/ } \\
\text { dl) }\end{array}$ & $134.65 \pm 17.12$ & $107.05 \pm 31.73$ & $<0.05$ \\
\hline $\begin{array}{c}\text { PPBS } \\
\text { (mg/dl) }\end{array}$ & $182.05 \pm 23.54$ & $129.45 \pm 8.96$ & $<0.05$ \\
\hline
\end{tabular}

Table 2: Demographic and biochemical profile of DM with healthy subjects.

\begin{tabular}{|c|c|c|c|c|}
\hline \multicolumn{2}{|c|}{ Parameter } & \multirow{2}{*}{$\begin{array}{c}\begin{array}{c}\text { Diabetics with } \\
\text { COPD (Group A) }\end{array} \\
1.88 \pm 0.5\end{array}$} & \multirow{2}{*}{\begin{tabular}{|c|}
$\begin{array}{c}\text { Healthy } \\
\text { Subjects (Group } \\
\text { C) }\end{array}$ \\
$2.72 \pm 0.52$ \\
\end{tabular}} & \multirow{3}{*}{$\begin{array}{c}\begin{array}{c}\text { Unpaired ' } t \text { ' } \\
\text { test } p \text { value }\end{array} \\
<0.05\end{array}$} \\
\hline \multirow{2}{*}{ FVC } & $\begin{array}{l}\text { Absolute }(\mathrm{L}) \\
\text { (Mean } \pm \mathrm{SD})\end{array}$ & & & \\
\hline & $\begin{array}{l}\% \text { Predicted } \\
(\text { Mean } \pm \text { SD })\end{array}$ & $61.35 \pm 11.52$ & $79.02 \pm 4.92$ & \\
\hline \multirow{2}{*}{ FEV1 } & $\begin{array}{l}\text { Absolute }(\mathrm{L}) \\
\text { (Mean } \pm \mathrm{SD})\end{array}$ & $1.16 \pm 0.32$ & $2.31 \pm 0.31$ & \multirow{2}{*}{$<0.05$} \\
\hline & $\begin{array}{l}\% \text { Predicted } \\
(\text { Mean } \pm \text { SD) }\end{array}$ & $49.30 \pm 12.99$ & $78.35 \pm 6.41$ & \\
\hline \multirow{2}{*}{$\begin{array}{l}\text { FEV1/ } \\
\text { FVC }\end{array}$} & $\begin{array}{l}\text { Absolute }(\mathrm{L}) \\
\text { (Mean } \pm \mathrm{SD})\end{array}$ & $67.05 \pm 14.85$ & $62.8 \pm 6.42$ & \multirow{2}{*}{$0.31(>0.05)$} \\
\hline & $\begin{array}{l}\% \text { Predicted } \\
\text { (Mean } \pm \text { SD) }\end{array}$ & $81.90 \pm 17.25$ & $78.80 \pm 8.35$ & \\
\hline \multirow{2}{*}{$\begin{array}{c}\text { FEF } 25- \\
75 \%\end{array}$} & $\begin{array}{l}\text { Absolute }(\mathrm{L}) \\
\text { (Mean } \pm \mathrm{SD})\end{array}$ & $0.96 \pm 0.59$ & $3.62 \pm 1.32$ & \multirow{2}{*}{$<0.05$} \\
\hline & $\begin{array}{l}\% \text { Predicted } \\
\text { (Mean } \pm \text { SD) }\end{array}$ & $1.31 \pm 0.51$ & $3.67 \pm 0.46$ & \\
\hline \multicolumn{2}{|c|}{$\begin{array}{l}\text { PEFR (Mean } \pm \text { SD })(\mathrm{L} / \\
\text { min })\end{array}$} & $208 \pm 68.77$ & $338 \pm 64.32$ & $<0.05$ \\
\hline
\end{tabular}

Table 3: Comparison of PFT in type 2 DM with COPD (Group A) and healthy controls (Group C).

history, physical examination, basic and specific investigation. For the purpose of meticulous data collection, a proforma was prepared and filled for every patient. Collected data was entered regularly in the MS EXCEL 2016 sheet and then by using SPSS the demographic, biochemical and spiromeric parameters compared by Unpaired ' $\mathrm{t}$ ' test and the association with duration was estimated by one-way ANOVA test. Observations and results were compared with other similar studies done in India and across the World.

DM being a systemic disease, which also affects lungs causing restrictive type of ventilatory changes, because of glycosylation of connective tissues, reduced pulmonary elastic recoil and inflammatory changes in lungs. The histopathological changes in the lungs of diabetics are associated with the thickening of the alveolar epithelium and the pulmonary capillary basal lamina and also due to the reduced recoiling of the lung [14]. This is caused by biochemical alteration of connective 


\begin{tabular}{|c|c|c|c|c|}
\hline \multicolumn{2}{|c|}{ Parameter } & $\begin{array}{c}\text { Diabetics } \\
\text { Mellitus (Group }\end{array}$ & $\begin{array}{c}\text { Healthy Subjects } \\
\text { (Group C) }\end{array}$ & $\begin{array}{l}\text { Unpaired 't' } \\
\text { test } p \text { value }\end{array}$ \\
\hline \multirow{2}{*}{ FVC } & $\begin{array}{c}\text { Absolute }(\mathrm{L}) \\
\text { (Mean } \pm \mathrm{SD})\end{array}$ & $1.92 \pm 0.62$ & $2.72 \pm 0.52$ & \multirow{2}{*}{$<0.05$} \\
\hline & $\begin{array}{l}\text { \% Predicted } \\
(\text { Mean } \pm \text { SD) }\end{array}$ & $57.80 \pm 13.03$ & $79.02 \pm 4.92$ & \\
\hline \multirow{2}{*}{ FEV1 } & $\begin{array}{l}\text { Absolute }(\mathrm{L}) \\
\text { (Mean } \pm \text { SD) }\end{array}$ & $1.35 \pm 0.43$ & $2.31 \pm 0.31$ & \multirow{2}{*}{$<0.05$} \\
\hline & $\begin{array}{l}\% \text { Predicted } \\
(\text { Mean } \pm \text { SD) }\end{array}$ & $53.55 \pm 16.98$ & $78.35 \pm 6.41$ & \\
\hline \multirow{2}{*}{$\begin{array}{l}\text { FEV1/ } \\
\text { FVC }\end{array}$} & $\begin{array}{l}\text { Absolute }(\mathrm{L}) \\
(\text { Mean } \pm \text { SD) }\end{array}$ & $69.2 \pm 14.65$ & $62.88 \pm 6.42$ & \multirow{2}{*}{$0.175(>0.05)$} \\
\hline & $\begin{array}{l}\% \text { Predicted } \\
(\text { Mean } \pm \text { SD) }\end{array}$ & $83.90 \pm 17.29$ & $78.80 \pm 8.35$ & \\
\hline \multirow{2}{*}{$\begin{array}{l}\text { FEF 25- } \\
75 \%\end{array}$} & $\begin{array}{l}\text { Absolute }(\mathrm{L}) \\
\text { (Mean } \pm \text { SD) }\end{array}$ & $1.08 \pm 0.74$ & $3.62 \pm 1.32$ & \multirow{2}{*}{$<0.05$} \\
\hline & $\begin{array}{l}\% \text { Predicted } \\
(\text { Mean } \pm \text { SD) }\end{array}$ & $1.08 \pm 0.73$ & $3.67 \pm 0.46$ & \\
\hline \multicolumn{2}{|c|}{$\begin{array}{l}\text { PEFR (Mean } \pm S D)(\mathrm{L} / \\
\text { min) }\end{array}$} & $219 \pm 74.29$ & $338 \pm 64.32$ & $<0.05$ \\
\hline
\end{tabular}

Table 4: Comparison of PFT in type 2 DM (Group B) and healthy controls (Group C).

\begin{tabular}{|c|c|c|c|c|c|c|c|c|c|}
\hline \multirow{2}{*}{$\begin{array}{c}\text { Sr. } \\
\text { No }\end{array}$} & $\begin{array}{c}\text { Spirometric } \\
\text { abnormality }\end{array}$ & $\begin{array}{c}\text { Diabetics } \\
\text { with COPD } \\
\text { (Group A) }\end{array}$ & $\begin{array}{c}\text { Diabetes } \\
\text { Mellitus } \\
\text { (Group B) }\end{array}$ & \multicolumn{2}{|c|}{$\begin{array}{c}\text { Healthy } \\
\text { subjects } \\
\text { (Group C) }\end{array}$} & \multicolumn{2}{|c|}{ Total } \\
\cline { 2 - 10 } & No & $\%$ & No & $\%$ & No & $\%$ & No & $\%$ \\
\hline 1 & Restriction & 22 & $55 \%$ & 26 & $65 \%$ & 2 & $5 \%$ & 50 & $41.66 \%$ \\
\hline 2 & Obstruction & 12 & $30 \%$ & 6 & $15 \%$ & 1 & $2.50 \%$ & 19 & $15.83 \%$ \\
\hline 3 & Mixed & 6 & $15 \%$ & 6 & $15 \%$ & 4 & $10 \%$ & 16 & $13.33 \%$ \\
\hline 4 & Normal & 0 & $0 \%$ & 2 & $5 \%$ & 33 & $82.50 \%$ & 35 & $29.16 \%$ \\
\hline & Total & 40 & $100 \%$ & 40 & $100 \%$ & 40 & $100 \%$ & 120 & $100 \%$ \\
\hline
\end{tabular}

Table 5: Spirometric abnormality comparison.

\begin{tabular}{|c|c|c|c|}
\hline Duration & FEV1(L) (Mean \pm SD) & $\begin{array}{c}\text { FVC(L) (Mean } \\
\mathbf{\pm} \text { SD) }\end{array}$ & $\begin{array}{c}\text { FEV1/FVC (Mean } \\
\pm \text { SD) }\end{array}$ \\
\hline$<5$ yrs. $(n=13)$ & $1.18 \pm 0.22$ & $2.01 \pm 0.59$ & $78.28 \pm 20.23$ \\
\hline $\begin{array}{c}5-9 \text { yrs. } \\
(n=15)\end{array}$ & $1.09 \pm 0.43$ & $1.69 \pm 0.42$ & $86.22 \pm 19.01$ \\
\hline $\begin{array}{c}10-15 \text { yrs } \\
(n=8)\end{array}$ & $1.28 \pm 0.26$ & $2.07 \pm 0.45$ & $74.25 \pm 11.84$ \\
\hline$>15$ yrs. $(n=4)$ & $1.04 \pm 0.21$ & $1.72 \pm 0.39$ & $84.24 \pm 17.24$ \\
\hline $\begin{array}{c}\text { ANOVA p } \\
\text { value }\end{array}$ & $F=0.429, p=0.658, N S$ & $\begin{array}{c}F=1.191, p=0.328, \\
\text { NS }\end{array}$ & $\begin{array}{c}F=0.607, p=0.556, \\
\text { NS }\end{array}$ \\
\hline
\end{tabular}

Table 6: Association of spirometry parameters with duration of DM in group A $(n=40)$.

\begin{tabular}{|c|c|c|c|}
\hline Duration & $\begin{array}{c}\text { FEV1(L) (Mean } \pm \\
\text { SD) }\end{array}$ & $\begin{array}{c}\text { FVC(L) (Mean } \\
\mathbf{\pm} \text { SD) }\end{array}$ & $\begin{array}{c}\text { FEV1/FVC (Mean } \\
\mathbf{\pm} \text { SD) }\end{array}$ \\
\hline$<5$ yrs. $(n=6)$ & $1.45 \pm 0.41$ & $2.01 \pm 0.59$ & $78.28 \pm 20.23$ \\
\hline 5 -9 yrs. $(n=18)$ & $1.35 \pm 0.29$ & $1.69 \pm 0.42$ & $86.22 \pm 19.01$ \\
\hline $10-15$ yrs $(n=12)$ & $1.40 \pm 0.58$ & $2.07 \pm 0.45$ & $74.25 \pm 11.84$ \\
\hline$>15$ yrs. $(n=4)$ & $1.60 \pm 0.79$ & $1.72 \pm 0.39$ & $84.24 \pm 17.24$ \\
\hline ANOVA $p$ value & $\begin{array}{c}F=0.162, p=0.921, \\
\text { NS }\end{array}$ & $\begin{array}{c}F=1.147, \\
p=0.360, N S\end{array}$ & $\begin{array}{c}F=5.073, p=0.112 \\
\text { NS }\end{array}$ \\
\hline
\end{tabular}

Table 7: Association of spirometry parameters with duration of DM in group $B$ $(n=40)$.

tissue constituents, particularly collagen and elastin. There is increased cross-linkage formation between polypeptides of collagen which leads to thickening, leading to restriction of lung volume and alveolar gas transport, reduced membrane diffusion capacity and pulmonary capillary blood volume $[15,16]$.

Mishra et al. [17] in a study of 15 patients with COPD with DM demonstrated that $73 \%$ patients had the probability of restrictive pattern of spirometry. In the present study, the high proportion (55\%) of patients having the restrictive pattern of spirometry. Possible reason for such high proportion of restrictive component in these patients could be the independent decline in FEV1 and FVC known to be associated with diabetes which causes pulmonary microangiopathy. In present study FEV1, FVC, FEF 25-75 and PEFR reduced as compared to healthy controls but FEV1/FVC was nearly same as that of controls, it correlates with other studies done by Kinney et al. [18] and Adiody et al. [19].

Irfan et al. [9], studied spirometric parameters in 64 diabetics and showed that there was significant reduction in FEV1, FVC when compared with healthy controls. Davis et al. [20] also showed that reduced lung volume is result of chronic complications of diabetes. Sreekumar et al. [21] also studied spirometric parameters in 100 diabetics and found that diabetics had decreased lung volumes (FVC, FEV1, FEV1/FVC and PEFR) as compared to healthy controls. Also the possible mechanisms are micro-vascular changes in the lung tissue will lead to impairment in lung functions studies also shown that T2DM with microangiopathy show reduced diffusion capacity. Yadav et al. [22] also studied pulmonary parameters in $30 \mathrm{DM}$ type 2 and found that FVC, FEV1, FEF 25-75, PEFR were significantly reduced except FEV1/FVC as compared to healthy controls, this study also found that there are $22(73.33 \%)$ cases out of 30 show restrictive pattern on spirometry. The FEV1/FVC\% in our study was lower than normal and was found to have restrictive pattern. This is in concordance Boulbou et al., [23], Sreeja et al. [24], Fimognari et al. [25]. PEFR was also reduced in our study which was similar to Sreeja et al. [24]. In present study of cases with type 2 DM shows that FVC, FEV1, FEF 25-75, PEFR were significantly reduced except FEV1/FVC as compared to healthy controls and It correlates with other studies done by Sanjeev Verma et al. [26] Irfan et al. [9], El-Azeem et al. [27], Kalappan et al. [28], Shah et al. [29].

In the study group of COPD with DM, There is no association between mean absolute FEV1, FVC and FEV1/FVC and duration of diabetes as the $\mathrm{P}$ values for FEV1, FVC and FEV1/FVC were 0.658 , 0.328 and 0.556 respectively which were statistically not significant. It means mean absolute values of FEV1, FVC and FEV1/FVC does not related to duration of DM and there was no change in above parameters in relation to increase in duration of DM.

In the study group of DM There is no association between FEV1, FVC and FEV1/FVC and duration of diabetes as the P values for FEV1, FVC and FEV1/FVC were $0.921,0.360$ and 0.112 respectively which were statistically not significant. It correlates with other studies done by El-Azeem et al. [27] Shah et al. [29] in these studies they found no statistical significance. As per our present study duration of DM was probably not the major determinant of lung pathology, which needs further research.

Our study has some limitations such as due to resource limited setup we could not go into the details of risk factors of type 2 Diabetes Mellitus and effect of poor glycaemic control ( $\mathrm{HbA1c}$ ) on lung function tests, the study size was small and we cannot analyse the result in different ethnic groups and Large, long term, prospective, randomized controlled studies are necessary to more fully evaluate effect of type 2 Diabetes Mellitus and Duration of DM on lung function tests.

This study showed that lung functions in term of FEV1, FVC, FEF 
Citation: Giri SG, Kapse VR, Barade SB, Mhaisekar DG (2019) Study of Pulmonary Function Test in Type 2 Diabetics and COPD with Diabetes. J Pulm Respir Med 9: 485. doi: 10.4172/2161-105X.1000485

Page 5 of 5

25-75 and PEFR were reduced in Group A (DM with COPD) and Group B (DM) but FEV1/FVC didn't show any change as compared to healthy subjects in both the study groups.

It has been shown that DM is multisystem disease which is associated with continuous damage and dysfunction of various organs and also affects the lung functions. It seems prudent to add spirometry to the monitoring tool for DM associated lung involvement and sequelae.

\section{Conclusion}

We conclude that COPD with DM and only DM patients showed a decrease in Pulmonary Function Test (spirometry) values compared to healthy subjects. The finding in our study proved that patients with type 2 DM with COPD (Group A) showed additional restriction pattern on spirometry with compared usual obstructive pattern, also further we found that in patients with Type 2 DM (Group B) we also found restrictive pattern. So we can conclude that DM being a systemic disease also affects lung causing restrictive type of ventilatory changes. The restrictive changes probably because of glycosylation of connective tissues reduced pulmonary elastic recoil and inflammatory changes in lungs. As the type $2 \mathrm{DM}$ was predominantly associated with restrictive pattern, Routine spirometry screening in all diabetic patients will help to identify the pulmonary function changes earlier which is often detected late or missed. Duration of DM was probably not the major determinant of lung pathology, which needs further research. There is a need for periodically assessing the pulmonary functions in COPD with type $2 \mathrm{DM}$ patients and DM patients as spirometry remains a cost effective and simple diagnostic tool and its use can give warning signal for patients to take early therapeutic measures to control progression.

Hence we can recommend doing periodic spirometry to the patients of Type $2 \mathrm{DM}$ with COPD and Isolated Type $2 \mathrm{DM}$ to monitor the reduction in lung functions and prevent further progressive lung volume reduction.

\section{References}

1. Kumar V, Fausto N, Abbas AK, Cotran RS, Robbins SL (2005) Robbins and cotran pathologic basis of disease. Philadelphia pp: 1194-1195.

2. Williams textbook of endocrinology. Philadelphia pp: 1371-1435.

3. World Health Organization (2008) Factsheet: Diabetes No p: 312

4. Kings H, Aubert RE, Herman WH (1998) Global burden of diabetes 1995 to 2025: Prevalence, numerical estimates and projections. Diabetes Care 21: 1414-1431.

5. Sandler M (1990) Is the Lung being target organ in diabetes mellitus?. Arch Intern Med 150:1385-1388

6. Claire EW, Emma HB (2013) Metabolic syndrome and diabetes mellitus in COPD. In: Klaus FR, Jadwiga AW, Emiel FMW. Editor. Eur Respir Mongraph 59: $117-134$

7. Rogliani P, Luca G, Calzetta L, Segreti A, Lauro D, et al. (2015) Chronic obstructive pulmonary disease and diabetes. COPD Research Practice 51: 933-940.

8. Samantha F, Ehrlich A, Charles P, Quesenberry S, Stephen K, et al. (2010) Patients diagnosed with diabetes are at increased risk for asthma, chronic obstructive pulmonary diseases, pulmonary fibrosis, and pneumonia but not Lung cancer. Diabetes Care 33: 55-60.
9. Irfan M, Jabbar A, Haque AS, Awan S, Hussain F (2011) Pulmonary functions in patients with Diabetes Mellitus. Lung India 28: 89-92.

10. Pramodh V, Akhila NR (2015) Pulmonary function tests in type 2 diabetes. IOSR J Dental Med Sci 14: 44-47

11. El-Habashy MM, Agha MA, El-Basuni HA (2014) Impact of diabetes mellitus and its control on pulmonary function and cardiopulmonary exercise tests. Egypt J Chest Dis Tuberc 63: 471-476.

12. Pawers AC (2008) Diabetes Mellitus IN: Fauci AS, Braunwand E, Hauser SL (eds.) Harrisons principals of internal medicine. New York pp: 2275-2304.

13. Celli BR, MacNee W, Agusti A, Anzeueto A, Berg B, et al. (2004) Standards fo the diagnosis and treatment of patients with COPD: A summary of ATS/ERS position paper. Eur Respir J 23: 932-946.

14. Kuziemski K, Specjalski K, Jassem E (2011) Diabetic pulmonary microangiopathy-fact or fiction?. Pol J Endocr 62: 171-176.

15. Klein OL, Krishnan JA, Glick S, Smith LJ (2010) Systematic review of the association between lung function and type 2 diabetes mellitus. Diabet Med 27: $977-987$

16. Nandhini R, Sayed SS, Saikumar P (2012) Respiratory myopathy in type II diabetes mellitus. J Clin Diag Res 6: 354-357.

17. Mishra GP, Dhamgaye TM, Tayade BO, Amol BF, Amit SA, et al. (2012) Study of pulmonary function tests in diabetics with COPD or Asthma. Appl Cardiopulm Pathophysiol 16: 299-308.

18. Kinney GL, Blackshinn JL, Wan ES, Make B, Regan E, et al. (2014) Pulmonary function reduction in diabetes with and without chronic obstructive pulmonary disease. Diabetes Care 37: 389-395.

19. Adiody S, Narmadha MP, Menon AR, Varghese PR (2017) Impact of diabetes mellitus on pulmonary function tests in COPD patients. Int $\mathrm{J}$ Contemp Med Res 4: 795-797.

20. Davis WA, Knuiman M, Kendall P, Grange V, Timothy ME (2004) Glycemic exposure is associated with reduced pulmonary function in type 2 diabetes. Diabetes Care 27: 752-757.

21. Pachampalayam SS, Bagialakshami G, Mohamed HPS (2017) PFT in DM. IOSR J Dental Med Sci 16 pp: 01-05.

22. Yadav A, Saxena AK, Gaur K, Punjabi P, Meena G (2013) Study of pulmonary function tests in type 2 diabetes mellitus: Case control study. IOSR J Dental Med Sci 10: 74-77.

23. Boulbou MS, Gourgoulianis KI, Klisiaris VK, Tsikrikas TS, Stathakis NE, et al. (2003) Diabetes mellitus and lung function. Med Princ Pract 12: 87-91.

24. Sreeja K, Samuel E, Keshavachandran C, Shasidhar S (2003) Pulmonary functions in patients with Diabetes Mellitus. Indian J Physiol Pharmacol 47 87-93.

25. Fimognari FL, Pasqualetti $P$, Moro L, Franco A, Piccirillo G, et al. (2007) The association between metabolic syndrome and restrictive ventilatory dysfunction in older persons. J Gerontol A Biol Sci Med 62: 760-765.

26. Verma S, Goni M, Kudyar RP (2009) Assessment of pulmonary functions in patients with Diabetes Mellitus. JK science 11: 71-74.

27. Abd A, Azeem E, Hamdy G, Amin M, Rashad A (2013) Pulmonary function changes in diabetic lung. Egypt $J$ Chest Dis Tuberc 62: 513-517.

28. Kalappan M, Rajendran K, Suthakaran PK, Thangaraj P, Ganapathy G (2016) Study on comparison of pulmonary function tests among diabetic and nondiabetic patients in a tertiary care hospital. Int J Adv Med 3: 938-941.

29. Shah SH, Sonawane P, Nahar P, Vaidya S, Salvi S (2013) Pulmonary function tests in type 2 diabetes mellitus and their association with glycemic control and duration of the disease. Lung India 30: 108-112. 